\title{
Comparison of Hormonal Treatment Kisspeptin with GnRH and hCG on the some Reproductive Performance of Cyprus, Does during Non-Breeding Season
}

\author{
Maad Hasani AL-Ameri
}

Department of Surgery and Obstetrics, Faculty of Veterinary Medicine, University of Fallujah, 31002, Anbar, Iraq.

\begin{abstract}
The current study was conducted to investigate the influence of Kisspeptin, GnRH and hCG on some reproductive performance of Cyprus does during the non-breeding season. A total 55 Cyprus does 2-6 years old and averages $45 \mathrm{~kg}$ body weight. The does were randomly divided into five equal groups (11 does per group). The first group (B1) regarded as a control group, intramuscular injection with normal saline, whereas, the second (B2) and third (B3) groups were injected with 4 and $8 \mu \mathrm{g} / \mathrm{kg}$ body weight of Kisspeptin-10 intravenous respectively. The fourth (B4) and fifth (B5) groups were injected with hCG (250 IU / doe) and GnRH (20 $\mu \mathrm{g} /$ doe) intramuscular respectively. Bucks were introduced after $24 \mathrm{~h}$ of the treatment in all groups, ensuring that does exhibit estrus were mated for three consecutive estrus cycles. There were significantly in kilogram kids per goats joined in group B2 $(2.84 \pm 0.05 \mathrm{~kg})$ and then group B5 $(2.45 \pm 0.04 \mathrm{~kg})$ compared with other groups. The kilograms born per goat kidding $(\mathrm{P}<0.05)$ was lower in group B4 than other groups. Gestation length was significantly longest in group B1 as compared with other groups. Results showed that there were no significant different $(\mathrm{P}>0.05)$ male kid weight and female kid weight. In conclusion, kisspeptin-10 (4 $\mu \mathrm{g} / \mathrm{kg} /$ animal) enhanced kilogram kids per goats joined and then $\mathrm{GnRH}$ in Cyprus goat does during non- breeding season.
\end{abstract}

Keywords | Kisspeptin-10, GnRH, hCG , Cyprus goat, Non-breeding season, Reproduction

Received | March 01, 2019; Accepted | March 30, 2019; Published | May 08, 2019

*Correspondence | Maad Hasani Al-Ameri, Department of Surgery and Obstetrics, Faculty of Veterinary Medicine, University of Fallujah, 31002, Anbar, Iraq; Email: maad.hassani@uofallujah.edu.iq

Citation | Al-Ameri MH (2019). Comparison of hormonal treatment kisspeptin with GnRH and hCG on the some reproductive performance of cyprus, does during non-breeding season . Adv. Anim. Vet. Sci. 7(7): 537-542.

DOI | http://dx.doi.org/10.17582/journal.aavs/2019/7.7.537.542

ISSN (Online) | 2307-8316; ISSN (Print) | 2309-3331

Copyright (ㅇ 2019 Al-Ameeri. This is an open access article distributed under the Creative Commons Attribution License, which permits unrestricted use, distribution, and reproduction in any medium, provided the original work is properly cited.

\section{INTRODUCTION}

$\mathrm{I}^{\mathrm{r}}$ raq has a small population of goats, it is about 1.260 .481 head in 2016 (FAO, 2016). Local goat in Iraq consists of two breeds, Native goat and Meriz that are raised primarily for meat and milk production (Magid et al., 2003). Cyprus goats were introduced in Iraq and it's known as Damascus goat or Shami goats have some advantages Fertility, prolificacy as averaging 1.80 kids per doe kidding and dual purpose animal (meat and milk), however, it is considered a seasonal breeder which it starts in late August and extends through mid-December (Mavrogenis et al., 2006). The reproductive seasonality impact of variation on the price of meat and milk over the year, which affects the economy of farmers and the food industry (Gómez-Brunet et al.,
2012).To solve this problem, researchers and breeders used tools to develop relevant techniques to manipulate the sexual activity of animals (Delgadillo, 2011). There are many methods for manipulation of reproduction, one method by using hormonal of these treatments (Medan et al., 2002; Husein et al., 2005; Acar et al., 2013).

Kisspeptins are the peptide product of the Kiss1 gene and act to stimulate GnRH secretion (Gottsch et al., 2004; Messager et al., 2005). Kisspeptins are located in the ovine brain in the arcuate nucleus (ARC) and the dorso-lateral preoptic area (POA) (Estrada et al., 2006; Franceschini et al., 2006; Smith et al., 2007). These ARC cells transmit sex-steroid feedback (both negative and positive) to the GnRH neurons (Smith, 2009). There is a considerable 
body of evidence that this neuropeptide regulates seasonal reproduction (Revel et al., 2006; Clarke et al., 2009). The seasonal change in Kiss1 expression, the extent to which kisspeptin cells provide input to the $\mathrm{GnRH}$ neurons is greater during the breeding season than in the non-breeding season (Smith et al., 2008).

Nowadays, researchers are using kisspeptin which is considered gatekeeper of the hypothalamic-pituitary-gonadal (HPG) axis in which the hypothalamic GnRH plays a crucial role. Kisspeptin-10 can stimulate this axis of ewes in anestrus (Sebert et al., 2010) consequently the release of LH and FSH (Ezzat et al., 2009) at 20- 30 min after the second injection in anestrus does (Hashizume et al., 2010).

Gonadotropin releasing hormone $(\mathrm{GnRH})$ or human chorionic gonadotropin (hCG) injections are applied to improve the reproductive performance in anestrus goats (Medan et al., 2002; Rodríguez-Martínez et al., 2018). A strategy of reproductive performance included inducing estrus and ovulation (Cameron et al., 1988; Khan et al., 2003; González-Álvarez et al 2016).The hCG has an activity similar to luteinizing hormone (LH), while the $\mathrm{GnRH}$ acts on the pituitary gland, stimulates the release of LH and FSH and subsequently the secretion of steroid hormones from the gonads. These hormones when administrated in the luteal phase act indirectly or directly on the ovary generating the formation of an accessory corpus luteum and increasing the serum progesterone concentration (Ishida et al.,1999; Lankford et al., 2010). Increased the progesterone concentration (Moeini et al., 2013) led to improve the embryo survival (Lashari and Tasawar, 2010) and accelerate embryonic development and improve pregnancy rates (Nephew et al., 1994).

There is no available information about the effect of kisspeptin-10, hCG and GnRH on some reproductive performance of Cyprus does in non- breeding season.

\section{MATERIALS AND METHODS}

\section{Animals}

The present study was conducted in Ruminant Research in the Department of Agricultural Research Station / Ministry of Agriculture, Abu Ghraib /Baghdad (latitude 33 $20^{\circ} \mathrm{N}$ ). A total of 55 Cyprus does 2-6 old and averages $45 \mathrm{~kg}$ body weight. Goats were kept indoors at night, and allowed field grazing pasture near the station on day. Indoors, the goats were fed hay and concentrated diet. All does have free access to water and trace mineral salt blocks.

\section{ExPERIMENTAL Design}

During the non-breeding season in 22 June does were divided randomly into five groups (11 does per group). Be- fore starting the hormonal treatment were does weight. The first group $(47.6 \pm 1.24 \mathrm{~kg})$ control (B1) $0.9 \% \mathrm{NaCl}$ intramuscular injections are divided into two doses $(2 \mathrm{ml} /$ animal / dose). A second group $43.0 \pm 2.86 \mathrm{~kg}$ (B2) injected kisspeptin-10 intravenous (AnaSpec, Inc., USA) $4 \mu \mathrm{g}$ $/ \mathrm{kg} /$ animal. A third group $(46.6 \pm 3.77 \mathrm{~kg})(\mathrm{B} 3)$ injected kisspeptin-10 intravenous $8 \mu \mathrm{g} / \mathrm{kg} / \mathrm{animal}$. Divided doses based on preliminary results (Hashizume et al., 2010). Fourth group $43.04 \pm 3.00 \mathrm{~kg}$ (B4) hCG intramuscular injection (Chorulon, Intervet International BV, Boxmeer, Holland) $250 \mathrm{IU} /$ animal, divided two doses. A fifth group $44.7 \pm 2.49 \mathrm{~kg}$ (B5) GnRH intramuscular injection (Receptal, Intervet International BV, Boxmeer, Holland) 20 $\mu \mathrm{g} / \mathrm{animal}$ and divided two doses. All goats received all the treatments and carried out two doses at 2-h intervals. Ten fertile bucks introduced to the does of all groups, two bucks for each group for estrus detection and mating; started 24 hours after treatments and left to ten days. Estrus checked continuously by observation. The kidding performance of the does in all groups assessed by kidding data including kilogram kids per goats joined, kilograms born per goat kidding, gestation length, birth type, kid weight and sex which recorded.

\section{STATistical Analysis}

Statistical analysis was performed with the SPSS Statistics 24.0 (2016). Statistical significance was declared at $\mathrm{P}<0.05$.

\section{RESULTS}

In the present study, the effect of hormonal treatments on some reproductive performance of Cyprus goat does in non- breeding season summarized in Table 1 . There were significant differences $(\mathrm{P}<0.05)$ among treated groups on kilogram kids per goats joined. The results revealed that the mean kilogram kids per goats joined increased in group B2 $(2.84 \pm 0.05 \mathrm{~kg})$ than other groups. As shown in the Table 1 kilograms born per goat kidding had lower $(\mathrm{P}<0.05)$ in group $\mathrm{B} 4$ than other groups. Additionally the mean gestation length was significantly $(P<0.05)$. However, the gestation length increased in group B1 compared to other groups. No significant differences were detected in male kid weight and female kid weight (Table 1). The significantly $(\mathrm{P}<0.05)$ higher in overall kids weight $(\mathrm{kg})$ in groups (B2, B1, B3 and B5) than B4 group.

The percent of Cyprus goat does showing different birth type based on treatments is presented in Table 2. Birth type proportions for twinning were higher $(\mathrm{P}<0.05)(80 \%)$ and $(72.73 \%)$ in $\mathrm{B} 5$ and $\mathrm{B} 3$ groups respectively followed by in single $(\mathrm{P}<0.05)(40 \%)$ in $\mathrm{B} 4$ group and triplet $(\mathrm{P}<0.05)$ in $\mathrm{B} 1$ group. The sex ratio of kids was higher $60 \%$ male in B1 group and 70\% female in B4 group (Table 2). 
Table 1: Effect of hormonal treatments on the some reproductive performance of Cyprus does during non-breeding season (Mean \pm SE).

\begin{tabular}{|c|c|c|c|c|c|c|c|c|}
\hline \multirow{2}{*}{$\begin{array}{l}\text { Parameters } \\
\text { Treatments }\end{array}$} & \multirow{2}{*}{$\begin{array}{l}\text { No of } \\
\text { goats }\end{array}$} & \multirow{2}{*}{$\begin{array}{l}\text { Kgs kids per } \\
\text { goats joined }\end{array}$} & \multirow{2}{*}{$\begin{array}{l}\text { Kgs born per } \\
\text { goat kidding }\end{array}$} & \multirow{2}{*}{$\begin{array}{l}\text { G e s t a tion } \\
\text { length (days) }\end{array}$} & \multicolumn{4}{|c|}{ kids weight (kg) } \\
\hline & & & & & Male & Female & & Overall \\
\hline B1 & 11 & $\begin{array}{l}1.70 \pm 0.06 \\
\mathrm{~cd}\end{array}$ & $\begin{array}{c}3.11 \pm 0.12 \\
\mathrm{a}\end{array}$ & $\begin{array}{c}153.17 \pm 0.83 \\
\mathrm{a}\end{array}$ & $\begin{array}{c}2.24 \pm 0.31 \\
\mathrm{a}\end{array}$ & $2.50 \pm 0.43$ & $\mathrm{a}$ & $\begin{array}{c}3.11 \pm 0.48 \\
\mathrm{a}\end{array}$ \\
\hline B2 & 11 & $\begin{array}{c}2.84 \pm 0.05 \\
\mathrm{a}\end{array}$ & $\begin{array}{c}3.12 \pm 0.06 \\
\mathrm{a}\end{array}$ & $\begin{array}{c}150.70 \pm 0.66 \\
\mathrm{~b}\end{array}$ & $2.11 \pm 0.19 \quad \mathrm{a}$ & a $2.38 \pm 0.40$ & $\mathrm{a}$ & $\begin{array}{c}3.12 \pm 0.37 \\
\mathrm{a}\end{array}$ \\
\hline B3 & 11 & $\begin{array}{c}1.95 \pm 0.05 \\
\mathrm{~b}\end{array}$ & $\begin{array}{c}3.07 \pm 0.08 \\
\mathrm{a}\end{array}$ & $\begin{array}{c}150.29 \pm 0.64 \\
\mathrm{~b}\end{array}$ & $2.05 \pm 0.12 \quad \mathrm{a}$ & a $2.25 \pm 0.44$ & $\mathrm{a}$ & $\begin{array}{c}3.07 \pm 0.33 \\
\mathrm{a}\end{array}$ \\
\hline B4 & 11 & $\begin{array}{l}1.63 \pm 0.03 \\
\mathrm{~cd}\end{array}$ & $\begin{array}{c}2.55 \pm 0.05 \\
\mathrm{~b}\end{array}$ & $\begin{array}{c}150.29 \pm 0.68 \\
\mathrm{~b}\end{array}$ & $1.78 \pm 0.03 \quad$ a & a $2.51 \pm 0.38$ & $\mathrm{a}$ & $\begin{array}{c}2.55 \pm 0.32 \\
\mathrm{~b}\end{array}$ \\
\hline B5 & 11 & $\begin{array}{c}2.45 \pm 0.04 \\
\mathrm{ab}\end{array}$ & $\begin{array}{c}3.03 \pm 0.07 \\
\mathrm{a}\end{array}$ & $\begin{array}{c}150.22 \pm 0.61 \\
\mathrm{~b}\end{array}$ & $2.27 \pm 0.37 \quad$ a & a $1.95 \pm 0.26$ & $\mathrm{a}$ & $\begin{array}{c}3.03 \pm 0.30 \\
\mathrm{a}\end{array}$ \\
\hline
\end{tabular}

Means within the column with different letters are significantly different $(\mathrm{p}<0.05)$.

$\mathrm{B} 1=2 \mathrm{ml}(0.9 \% \mathrm{NaCl})$ (control), B2 (4 $\mu \mathrm{g} / \mathrm{kg} /$ animal) kisspeptin, B3 (8 $\mu \mathrm{g} / \mathrm{kg} /$ animal) kisspeptin , B4 (250 IU hCG / animal) and B5 $(20 \mu \mathrm{g} /$ animal $\mathrm{GnRH})$.

Table 2: Birth type and sex ratio

\begin{tabular}{|c|c|c|c|c|c|c|c|c|}
\hline \multirow[t]{2}{*}{ Treatments } & \multicolumn{3}{|c|}{ Birth type } & \multirow[t]{2}{*}{ Overall } & \multirow{2}{*}{$\begin{array}{l}\text { No. of } \\
\text { Male }\end{array}$} & \multirow[t]{2}{*}{$\%$} & \multirow{2}{*}{$\begin{array}{l}\text { No. of } \\
\text { Female }\end{array}$} & \multirow[t]{2}{*}{$\%$} \\
\hline & Single & Twin & Triplets & & & & & \\
\hline B1 & $\begin{array}{c}3 \\
(30 \%) b\end{array}$ & $\begin{array}{c}2(4) \\
(40 \%) \mathrm{d}\end{array}$ & $\begin{array}{c}1(3) \\
(30 \%) \mathrm{a}\end{array}$ & 10 & 6 & 60 & 4 & 40 \\
\hline B2 & $\begin{array}{c}4 \\
(23.53 \%) c\end{array}$ & $\begin{array}{c}5(10) \\
(58.82 \%) \mathrm{c}\end{array}$ & $\begin{array}{c}1(3) \\
(17.65 \%) \mathrm{b}\end{array}$ & 17 & 9 & 52.95 & 8 & 47.05 \\
\hline B3 & $\begin{array}{c}3 \\
(27.27 \%) \mathrm{b}\end{array}$ & $\begin{array}{c}4(8) \\
(72.73 \%) \mathrm{b}\end{array}$ & - & 11 & 5 & 45.45 & 6 & 54.55 \\
\hline B4 & $\begin{array}{c}4 \\
(40 \%) \mathrm{a}\end{array}$ & $\begin{array}{c}3(6) \\
(60 \%) c\end{array}$ & - & 10 & 3 & 30 & 7 & 70 \\
\hline B5 & $\begin{array}{c}3 \\
(20 \%) \mathrm{d}\end{array}$ & $\begin{array}{c}6(12) \\
(80 \%) \mathrm{a}\end{array}$ & - & 15 & 7 & 46.66 & 8 & 53.34 \\
\hline
\end{tabular}

Means within the column with different letters are significantly different $(\mathrm{p}<0.05)$.

B1 = $2 \mathrm{ml}(0.9 \% \mathrm{NaCl})$ (control), B2 (4 $\mu \mathrm{g} / \mathrm{kg} /$ animal) kisspeptin, B3 (8 $\mu \mathrm{g} / \mathrm{kg} /$ animal) kisspeptin , B4 (250 IU hCG / animal) and B5 (20 $\mu$ g/ animal GnRH).

\section{DISCUSSION}

New strategies for the manipulation of reproduction in seasonal breeders by kisspeptin system. Kisspeptin changed in reproductive function during seasonality acyclic females which it reduced expression in the arcuate nucleus during non-breeding season as results increased negative feedback of estrogen on GnRH secretion (Clarke et al., 2009). Therefore, the process of correcting lower levels of kisspeptin in anestrous by infusion of kisspeptin (Smith, 2012) led to change gonadotropin secretion and ovaries that responses to synchronize LH surges and cause ovulation (Caraty et al., 2007).

The effect of exogenous kisspeptin-10 to stimulate LH and FSH-release in goats has been reviewed by Hashizume et al. (2010) who indicated that it given 1,5 or $10 \mu \mathrm{g} / \mathrm{kg} /$ animal at 2-h intervals of i.v. injection of kisspeptin-10 led to stimulate $\mathrm{LH}$ at $20-30 \mathrm{~min}$ after the second injection.

In the present study, the effect of hormonal treatments on some reproductive performance of Cyprus goat does in non- breeding season. There were significant differences $(\mathrm{P}<0.05)$ among treated groups on kilogram kids per goats joined. The results illustrated that the mean kilogram kids per goats joined increased in group B2 $(2.84 \pm 0.05 \mathrm{~kg})$ than other groups. These results agreed with findings (Hashizume et al., 2010) in the present study that injection of Kisspeptin-10 (4 $\mu \mathrm{g} / \mathrm{kg} / \mathrm{animal})$ and $(8 \mu \mathrm{g} / \mathrm{kg} / \mathrm{animal})$ at 2 -h intervals. In contrast, injection single dose $(1 \mu \mathrm{g} / \mathrm{kg} /$ animal) of Kisspeptin-10 did not stimulate the release of LH during the anestrous in female goats (Arjmand et al., 2014).

The results of the present study showed that hormonal treatments caused the significant increase in kilogram kids 
per goats joined. Kisspeptin-10 can stimulate the quiescent hypothalamo- hypophyseal-ovarian axis in anestrus. Caraty et al. (2007) reported that infusion of Kisspeptin-10 led to elevate plasma LH levels and caused to synchronize LH surges in progesterone-primed and ovulation. In addition, Sebert et al.(2010) reported that kisspeptin increase LH surge in $75 \%$ of treated animals within $24 \mathrm{~h}$ after initiation of kisspeptin-10. Caraty et al. (2012) observed that kisspeptin stimulate to activate ovarian function, increase ovarian steroidogenesis andovulation.

These studies illustrate the ability of kisspeptin to stimulate hypothalamo- hypophyseal-ovarian axis during non-breeding season in Cyprus does led to induce ovaries function, secretion E2, higher ovulation rate, high conception rate and production of embryos. These hypotheses support data result in the present study to increase kilogram kids per goats joined in group B2 and less in group B3. On the other hand, increased serum concentration of $\mathrm{P} 4$ as result induced the formation of accessary corpus luteum (Fernandez et al., 2018). It has been reported that (Bazer et al., 1998) there were interactions between the conceptus, uterus and ovaries that require the continued actions of progesterone. Lankford et al. (2010) provide evidence that increased serum $\mathrm{P} 4$ concentrations as result increased the number of corpus luteum that reduces embryonic mortality.

In the present study, increase kilogram kids per goats joined in groups B2 and B5 than other groups indicated maintenance of pregnancy that is require elevated progesterone and protect the corpus luteum during early pregnancy and inhibition prostaglandin F2 $\alpha$ from uterine by interferon-tau (IFNT) from the elongating embryo (Wiltbank et al., 2018) and accelerate embryonic development and improve pregnancy rates (Nephew et al., 1994). However, the results obtained in this study in group B5 agreement with (Medan et al., 2002; Husein et al., 2005; Zonturlu et al., 2018). In contrast, decrease kilogram kids per goats joined in group B4 was similar to other studies reported (Fonseca et al., 2005; Dias et al., 2018) hCG treated to improve ovulation synchronization and in contrast decrease in the pregnancy rate. Provide evidence that decrease kilograms born per goat kidding in group B4 as compared with other groups.

The breeding season in Cyprus goat onset in late August (Mavrogenis et al., 2006). Goats in group B1 showed estrus when breeding season starts in this time. However, decrease kilogram kids per goats joined in group B1 than other groups that indicate provide evidence that the effect of hormonal treatments increase kilogram kids per goats joined and distinguish goats treated kisspeptin-10 (4 $\mu \mathrm{g} / \mathrm{kg} /$ animal) group B2 and GnRH group B5 during non-breeding season.
From the results of the present study, gestation length in group B1 was the longest compare with groups due to external and internal factors such as breeds, breeding season, litter weight and parity (Mellado et al 2000). On the other hand, Ruvuna et al. (1988) reported that differences in the gestation length due to season of kidding and litter size. Mellado et al. (2000); Haldar and Ghosh. (2015) pointed out that gestation length was longer one day if goats mated in summer compare to mate in autumn. However, gestation length within an acceptable ranges (Haldar and Ghosh, 2015).

In the current study, the effect of hormonal treatments produced a higher proportion of twins in B5 and B3 groups. However, Cameron et al. (1988) reported that increased ovulation rate of goats treated with $\mathrm{GnRH}$. Caraty et al. (2012) pointed out that kisspeptin increase ovarian steroidogenesis and ovulation. In addition, there were differences between B2 and B3 groups as results increase ovulation rate in B2 group than B3 group due to use dose kisspeptin-10 (4 $\mu \mathrm{g} / \mathrm{kg} /$ animal) vs. $(8 \mu \mathrm{g} / \mathrm{kg} / \mathrm{animal})$ lead to obtain 1 Triplets in B2 group. These results provide evidence that lower levels of kisspeptin in anestrous (Smith, 2012) led to change gonadotropin secretion and ovaries that response to synchronize LH surges and cause ovulation (Caraty et al., 2007). On the other hand, birth type difference among groups as results the number of ovulations and time of ovulation (Simoes et al., 2008; Ince, 2010).

In the present study, sex ratio of kids was higher $60 \%$ male in B1 group. These results agreement with Sivakumar and Soundararajan, (2006) reported that the percentage of male was higher all the seasons except during summer. In contrast, it has been reported that Abecia et al. (2017) there were not differ significantly affect lunar phase and season on offspring sex ratio in goats. On the other hand, sex ratio of kids was higher 70\% female in B4 group may be there were factors such as timing of hormonal treatments and mating which related to change sex ratio of kids. However, decreased female weight in B4 group due to most kids born to female's agreement with Al-Shaikh and Mogawer, (2001) who found that birth weight of male kid was higher than that of the female kid.

\section{CONCLUSION}

It can be concluded that the use of hormonal treatments kisspeptin-10, GnRH and hCG are very effective for stimulating hypothalamo- hypophyseal-ovarian axis in Cyprus does during the non-breeding season. The results of this study indicate that kisspeptin-10 (4 $\mu \mathrm{g} / \mathrm{kg} / \mathrm{animal})$ enhanced kilogram kids per goats joined and then GnRH, increased proportions for twinning by using $\mathrm{GnRH}$ and kisspeptin-10 (8 $\mu \mathrm{g} / \mathrm{kg} / \mathrm{animal})$ and increased number of 
OPEN OACCESS

kids by using kisspeptin-10 ( $4 \mu \mathrm{g} / \mathrm{kg} / \mathrm{animal})$ in Cyprus does during the non- breeding season.

\section{REFERENCES}

- Abecia JA, Arrebola F, Palacios C (2017). Offspring sex ratio in sheep, cattle, goats and pigs: influence of season and lunar phase at conception. Biol. Rhythm Res. 48(3): 417-424. http://dx.doi.org/10.1080/09291016.2016.1268325.

- Acar DB, Birdane MK, Özenc E, Yeni D, Dogan I (2013). Effectiveness of different progesterone analogues and $\mathrm{GnRH}$ on reproductive parameters in nulliparous Saanen goats at the end of the transition period. Kafkas. Univ. Vet. Fak. Derg. 19 (Suppl-A): A181-A186. http://doi: 10.9775/ kvfd.2013.8747.

-Al-Shaikh MA, Mogawer HH (2001). Factors affecting body weight of Aardi goat kids in Saudi Arabia. J. Appl. Anim. Res. 20: 233-238. https://doi.org/10.1080/09712119.2001. 9706757

-Arjmand M, Mirzaei A, Shirazi MRJ, Tamadon A, Salehi MS, Saeb M, Namavar MR, Zandi MR, Shahheidari H, Moradi $S$ (2014). Luteal activity of Abadeh ecotype does in summer and winter and the effect of kisspeptin-10 on luteinizing hormone secretion in the anestrus does. Vet. Res. Forum. 5(4): 247 - 254.

- Bazer FW, Ott TL, Spencer TE (1998). Maternal recognition of pregnancy: comparative aspects. Trophoblast. Res. 12: 375386. https://doi.org/10.1016/S0143-4004(98)80055-6

- Cameron AW, Battye KM, Trounson AO (1988). Time of ovulation in goats (Capra bircus) induced to superovulate with PMSG. J. Reprod. Fertil. 83: 747-752. https://doi. org/10.1530/jrf.0.0830747

- Caraty A, Smith JT,Lomet D, Ben Saïd S, Morrissey A, Cognie J, Doughton B, Baril G, Briant C, Clarke IJ (2007). Kisspeptin synchronizes preovulatory surges in cyclical ewes and causes ovulation in seasonally acyclic ewes. Endocrinology. 148: 5258- 5267. http://doi: 10.1210/en.2007-0554.

- Caraty A, Decourt C, Briant C, Beltramo M (2012). Kisspeptins and the reproductive axis: potential applications to manage reproduction in farm animals. Domest.Anim. Endocrinology. 43: 95-102. http://dx.doi.org/10.1016/j.domaniend.

- Clarke IJ, Smith JT, Caraty A, Goodman RL, Lehman MN (2009). Kisspeptin and seasonality in sheep. Peptides. 30(1): 154-163. http:// doi:10.1016/j.peptides.2008.08.022.

-Delgadillo JA (2011). Environmental and social cues can be used in combination to develop sustainable breeding techniques for goat reproduction in the subtropics. Animal. 5(1): 74-81 https://doi.org/10.1017/S1751731110001400.

- Dias LMK, Sales JNS, Viau P, Barros MBP, Nicolau SS, Simões LMS, Alves NG, Alonso MA, Valentim R, Oliveira CA (2018). Although it induces synchronized ovulation, hCG reduces the fertility of Santa Ines ewes submitted to TAI. Arq. Bras. Med. Vet. Zootec. 70(1): 122-130. https://doi. org/10.1590/1678-4162-9679

-Estrada KM, Clay CM, Pompolo S, Smith JT, Clarke IJ (2006). Elevated KiSS-1 expression in the arcuate nucleus prior to the cyclic preovulatory gonadotrophin-releasing hormone/lutenising hormone surge in the ewe suggests a stimulatory role for kisspeptin in oestrogen-positive feedback. J. Neuroendocrinol. 18: 806-809. https://doi. org/10.1111/j.1365-2826.2006.01485.x

-Ezzat AA, Saito H, Sawada T, Yaegashi T, Yamashita T, Hirata
Advances in Animal and Veterinary Sciences

TI, Sawai K, Hashizume T (2009). Characteristics of the stimulatory effect of Kisspeptin-10 on the secretion of luteinizing hormone, follicle-stimulating hormone and growth hormone in prepubertal male and female cattle. J. Reprod. Dev. 55: 650-654. https://doi.org/10.1262/ jrd.20255

-FAO (2016). FAOSTAT Agriculture Data, Live Animals, Goats, Iraq. Accessed on August 24, 2018. http://www.fao. org/faostat

-Fernandez J, Bruno- Galarraga MM, Soto AT, de la Sota RL, Cueto MI, Lacau IM, Gibbons AE (2018). Hormonal therapeutic strategy on the induction of accessory corpora lutea in relation to follicle size and on the increase of progesterone in sheep. Theriogenology. 105: 184-188. https://doi.org/10.1016/j.theriogenology.2017.09.020

-Fonseca JF, Bruschi JH, Zambrini FN, Demczuk E, Viana JHM, Palhão MP (2005). Induction of synchronized estrus in dairy goats with different gonadotrophins. Anim. Reprod. 2(1): 50-53.

- Franceschini I, Lomet D, Cateau M, Delsol G, Tillet Y, Caraty A (2006). Kisspeptin immunoreactive cells of the ovine preoptic area and arcuate nucleus co-express estrogen receptor alpha. Neurosci. Lett. 401: 225-230. https://doi. org/10.1016/j.neulet.2006.03.039

-Gómez-Brunet A, Santiago-Moreno J, Toledano-Diaz A, López-Sebastián A (2012). Reproductive seasonality and its control in Spanish sheep and goats: A review. Tropical and Subtropical. Agro ecosystems. 15 (Suppl. 1): S47-S70.

-González-Álvarez VH, Meza-Herrera CA, Leyva C, AlvaradoEspino AS, Guillén-Muñoz JM, Rodríguez-Martínez R, Véliz-Deras FG (2016). Effectiveness of different hCG and $\mathrm{GnRH}$ based protocols in progesterone primed goats on estrus induction and reproductive outcomes in outoff-season goats. J. Anim. Res. 6(2): 177-182. https://doi. org/10.5958/2277-940X.2016.00031.0

- Gottsch ML, Cunningham MJ, Smith JT, Popa SM, Acohido BV, Crowley WF, Seminara S, Clifton DK, Steiner RA (2004). A role for kisspeptins in the regulation of gonadotropin secretion in the mouse. Endocrinology. 145: 4073-4077. https://doi.org/10.1210/en.2004-0431

- Haldar C, Ghosh S (2015). Dynamics and regulation of goat reproduction. Int. J. Curr. Res. Aca. Rev. 3(8): 20-36.

-Hashizume T, Saito H, Sawada T, Yaegashi T, Ezzat AA, Sawai K, Yamashita T (2010). Characteristics of stimulation of gonadotropin secretion by kisspeptin-10 in female goats. Anim. Reprod. Sci. 118: 37-41. http://doi:10.1016/j. anireprosci.2009.05.017

- Husein MQ, Ababneh MM, Haddad SG (2005). The effects of progesterone priming on reproductive performance of GnRH-PGF2 $\alpha$-treated anestrous goats. Reprod. Nutr. Dev. 45: 689-698. https://doi.org/10.1051/rnd:2005053

-Ince D (2010). Reproduction performance of Saanen goats raised under extensive conditions. Afr. J. Biotechnol. 9(48): 8253-8256. https://dol: 10.5897/AJB10.1345.

- Ishida N, Okada M, Sebata K, Minato M, Fukui Y (1999). Effects of GnRH and hCG treatments for enhancing corpus luteum function to increase lambing rate of ewes artificially inseminated during the non-breeding season. J. Reprod. Dev. 45: 73-79. https://doi.org/10.1262/jrd.45.73

-Khan TH, Hastie PM, Beck NFG, Khalid M (2003). hCG treatment on day of mating improves embryo viability and fertility in ewe lambs. Anim. Reprod. Sci.76: 81-89. https:// doi.org/10.1016/S0378-4320(02)00194-X 
- Lankford LM, Yates DT, Halalsheh RA, Black PL, Hallford DM, Ross TT (2010). Effects of human Chorionic Gonadotropin on serum progesterone concentrations, embryonic survival, and lambing rates in ewes. Proceedings, Western Section, American Society of Anim. Sci. 61:153157.

- Lashari MH, Z Tasawar (2010). The effect of GnRH given on day of mating on ovarian function and reproductive performance in Lohi sheep. Pakistan. Vet. J. 30(1): 29-33.

-Magid SA, Al-Murrani WK, Alkas JI (2003). Iraq country report animal genetic resources. Ministry Agric. p. 18-21.

- Mavrogenis AP, Antoniades NY, Hooper RW (2006). The Damascus (Shami) goat of Cyprus. AGRI. 38: 57-65. https://doi.org/10.1017/S1014233900002054

- Medan M, Shalaby AH, Sharawy S, Watanabe G, Taya K (2002). Induction of estrus during the non-breeding season in Egyptian Baladi goat. J. Vet. Med. Sci. 64(1): 83-85. https://doi.org/10.1292/jvms.64.83

- Messager S, Chatzidaki EE, Ma D, Hendrick AG, Zahn D, Dixon J, Thresher RR, Malinge I, Lomet D, Carlton MB, Colledge WH, Caraty A, Aparicio SA (2005). Kisspeptin directly stimulates gonadotropin-releasing hormone release via $G$ protein-coupled receptor 54. Proc. Natl. Acad. Sci. U.S.A. 102: 1761-1766. https://doi.org/10.1073/ pnas.0409330102

- Moeini MM, Alipour F, Sanjabi MR (2013). Efficacy of CIDR or FGA sponges with hCG treatments on the conception rate and prolificacy in Lori lwes out of the breeding season. Iranian J. Appl. Anim. Sci. 3(3): 521-525.

- Mellado M, Amaro JL, Garcia JE, Lara LM (2000). Factors affecting gestation length in goats and the effect of gestation period on kid survival. J. Agri. Sci. 135(1): 85-89. (Abstract) https://doi.org/10.1017/S0021859699007935.

- Nephew KP, Cardenas H, McClure KE, Ott TL, Bazer FW, Pope WF (1994). Effects of Administration of human Chorionic Gonadotropin or progesterone before maternal recognition of pregnancy on blastocyst development and pregnancy in sheep. J. Anim . Sci. 72: 453-458. https://doi. org/10.2527/1994.722453x

- Revel FG, Saboureau M, Masson-Pevet M, Pevet P, Mikkelsen JD, Simonneaux V (2006). Kisspeptin mediates the photoperiodic control of reproduction in hamsters. Curr. Biol. 16: 1730-1735. https://doi.org/10.1016/j. cub.2006.07.025

- Rodríguez-Martínez R, Meza-Herrera CA, Tapia-Robles KI, Alvarado-Espino AS, Luna-Orozco JR, Leyva C, Mellado M, Véliz-Deras FG (2018) . Effect of two routes of administration of human chorionic gonadotropin upon oestrus induction and reproductive outcomes in adult acyclic mix-breed goats. J. Appl. Anim. Res. 46(1): 190-194.https:// doi.org/10.1080/09712119.2017.1284075
- Ruvuna, F, Cartwright T C, Blackburn H, Okeyo M, Chema S (1988). Gestation length, birth weight and growth rates of pure-bred indigenous goats and their crosses in Kenya. J. Agric. Sci. 111(2): 363-368. https://doi.org/10.1017/ S0021859600083313

- Sebert ME, Lomet D, Said SB,Monget P,Briant C, Scaramuzzi RJ, Caraty A (2010). Insights into the mechanism by which kisspeptin stimulates a preovulatory LH surge and ovulation in seasonally-acyclic ewes: potential role of estradiol. Domest. Anim. Endocrinol. 38: 289-298.

- Simoes J, Baril G, Almeida JC, Azevedo J, Fontes P, Mascarenhas R (2008). Time of ovulation in nulliparous and multiparous goats. Animal. 2(5): 761-768. https://doi: 10.1017/S175173110800195X.

- Sivakumar T, Soundarataian C (2006). Factors affecting sex ratio in tellichery goats under intensive system. 1JFV. 2:1213.

-Smith JT, Clay C.M, Caraty A, Clarke IJ (2007). KiSS-1 messenger ribonucleic acid expression in the hypothalamus of the ewe is regulated by sex steroids and season. Endocrinology. 148: 1150-1157. https://doi.org/10.1210/ en.2006-1435

-Smith JT, Coolen LM, Kriegsfeld LJ, Sari IP,Jaafarzadehshirazi MR, Maltby M, Bateman K, Goodman RL, Tilbrook AJ, Ubuka T, Bentley GE, Clarke IJ, Lehman MN (2008). Variation in kisspeptin and RFamide-related peptide (RFRP) expression and terminal connections to gonadotropinreleasing hormone neurons in the brain: a novel medium for seasonal breeding in the sheep. Endocrinology. 149: 57705782. https://doi.org/10.1210/en.2008-0581

-Smith JT (2009). Sex steroid control of hypothalamic Kiss1 expression in sheep and rodents: comparative aspects. Peptides. 30: 94-102. https://doi.org/10.1016/j. peptides.2008.08.013

-Smith JT (2012). The role of kisspeptin and gonadotropin inhibitory hormone in the seasonal regulation of reproduction in sheep. Domest. Anim. Endocrinol. 43: 7584. https://doi:10.1016/j.domaniend.2011.11.003.

-SPSS (2016). Statistical Packages of Social Sciences. Version 24.

-Wiltbank MC, Mezera MA, Toledo MZ, Drum JN, Baez GM, García-Guerra A, Sartori R (2018). Physiological mechanisms involved in maintaining the corpus luteum during the first two months of pregnancy. Anim. Reprod. 15(Suppl.1): 805-821. https://doi.org/10.21451/19843143-AR2018-0045

-Zonturlu AK, Kaçar C, Kaya S, Emre B, Korkmaz Ö, Ar1 UÇ (2018). Effect of double GnRH injections on reproductive parameters in Awassi ewes receiving longterm progesterone. J. Appl. Anim. Res. 46(1): 1103-1107. https://doi.org/10.1080/09712119.2018.1469497. 